\title{
MUSEUM OF VERNACULAR ARCHITECTURE OF WESTERN SERBIA - Representative curtilages of the area surrounding middle course of the river Drina and Podgorina
}

\author{
Duško Kuzović ${ }^{1}$
}

\begin{abstract}
The Museum of vernacular architecture of western Serbia will consist of four representative curtilages and four different entities. This paper presents two curtilages representing the area of the middle course of the river Drina, and the area of Podgorina. The buildings typically located in the curtilage are: house, magaza (plural: magaze) - food storage shed, kačara (plural: kačare) - cask shed, vajat (plural: vajati) - cottage for newly-wed couples, granary, maize granary, bread oven, ox cart shed. The buildings are presented by drawings and photographs. The text describes curtilage organization; this comprises buildings position, organization and structure.
\end{abstract}

Key words: Vernacular architecture of Serbia, western Serbia, Museum of vernacular architecture, vernacular architecture, traditional architecture.

JEL: 013, O22, O44, Q19.

\section{Introduction}

Vernacular architecture of western Serbia must be protected as soon as possible so that the rare specimens of surviving buildings could be properly presented. It is necessary to gather the valuable specimens on one place, into a museum which would consist of several curtilages representing the characteristic spatial entities of western Serbia. The curtilages would include buildings such as houses, vajati, magaze, kačare, stables, granaries and maize granaries,

Stojan Obradović (Obradovic, 1858), Felix Kanitz (Kanic, 1985), wrote about the northern part of Užička Crna Gora and Sokolska nahija (district) in the second half of the $19^{\text {th }}$ century, while Ljuba Pavlović (Павловић, 1925), Jovan Cvijić (Цвијић, 1931) and Dragiša Pantelić (Пантелић, 1936) wrote about them in the beginning of $20^{\text {th }}$ century.

During the mid-20 th century, Branislav Kojić (Kojić, 1949; Kojić, 1941), Aleksandar Deroko (Deroko, 1968; Deroko, 1964), Jovan Krunić (Krunić, 1983), Ranko Findrik (Findrik, 1995; Findrik, 1998), Božidar Krstanović (Krstanović, 2000), Blagota Pešić (Pešić, 1991; Pešić,

1 Duško Kuzović Ph.D., Assistant Professor, Eastern Mediterranean University, Faculty of Architecture, TRN Cyprus, E-mail: dusko.kuzovic@gmail.com

EP 2017 (64) 1 (239-257) 
1988), etc., published on this topic as well. Milan Karanović (Karanović, 1927), Muhamed Kadić (Kadić, 1967), Špiro Soldo (Soldo, 1932) and Hamdija Kreševljaković (Kreševljaković, 1957) wrote about vernacular architecture in Bosnia and Herzegovina, which is very similar to that of western Serbia.

The task of this paper is to propose the elements and concepts for a representative curtilage in middle course of the river Drina area and Valjevo Podgorina within the Museum of vernacular architecture of western Serbia.

The goal of this paper is to identify the zones featuring characteristic building methods, define the contents of the curtilage and describe the typical outbuildings within a representative curtilage in the Museum.

The basic material for this paper is the material collected in the field in the 19962000 period and published in national and international scientific publications on the fundamentals of traditional architecture (Kuzović, 1996/1997; Kuzović, 1996), curtilage (Kuzović, 2014), houses (Kuzović, 2013; Kuzović, Крсмановић, 2013), vajati [cottages for newly-weds couples] (Kuzović, 2016), magaze [food storage sheds] (Kuzović, 2013), granaries (Kuzović, 2012), maize granaries (Kuzović, 2013), summer abodes (Kuzović, Stojnić, 2015), watermills and fulling mills (Kuzović, Stojnić, 2015), structural designs (Kuzović, 2012b; Kuzović, 2012a), elements of aesthetics and philosophy (Kuzović, Stojnić, 2014; Kuzović, Stojnić, 2013) and protection of vernacular architectonic heritage (Kuzović, 2013; Kuzović, 2015a; Kuzović, 2015b).

\section{CONCEPT OF THE MUSEUM AND COMPOSITION OF THE CURTILAGES}

\section{Concept of the museum}

The Museum presents Vernacular architecture of the central part area of western Serbia, bounded on the north by the river Sava valley, on the east by Suvobor mountain, on the south by the rivers Skrapež and Zapadna Morava, and on the west by the river Drina.

The museum will be composed of the central complex and four independent entities: summer abodes, watermills, buildings featuring specific designs, economy buildings and old crafts display. [Table 01]

This paper will analyze the material and the proposal for the curtilages characteristic for the middle course of the river Drina area and for the villages of the Valjevo Podgorina region.

It is an area bounded on the north by the town of Loznica valley, and on the south by the town of Bajina Bašta valley, on the west by Povlen mountain and on the east by the river Drina valley. [Figure 01] 
Table 1. Concept of the Museum

\begin{tabular}{|c|c|c|}
\hline \multicolumn{4}{|c|}{ CENTRAL EXIBITION } \\
Curtilage in the area of Povlen mountain \\
Curtilage in the rivers Skrapež and Lužnica valley areas \\
Curtilage in the middle course area of the river Drina \\
Curtilage in the area of Podgorina \\
\hline \multicolumn{4}{|c|}{ ENTITY 1 } & $\begin{array}{c}\text { ENTITY 2 } \\
\text { Summer abodes }\end{array}$ & ENTITY 3 & $\begin{array}{c}\text { ENTITY 4 } \\
\text { Eatermills }\end{array}$ & Specific structural designs & $\begin{array}{c}\text { Ecomy buildings and } \\
\text { old crafts }\end{array}$ \\
\hline
\end{tabular}

Source: Work of author

Figure 1. Western Serbia. Area represented by the Museum (dotted line) and the space presented in the paper (continuous line)

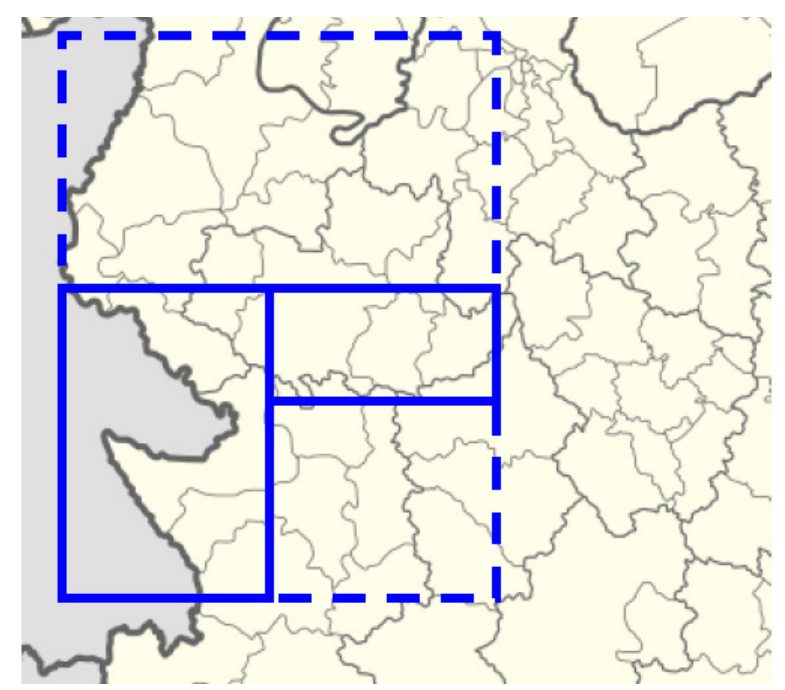

Source: Work of author

\section{Village curtilage of the Drina middle course area}

The curtilage consists of the house, two vajati [cottages small house for newly-wed couples], magaza [food storage shed], kačara [cask shed], ambar [granary], koš za kukuruz [maize granary], furuna [bread oven] and štala [stable], enclosed by a fence made of upright stakes and horizontal branches having several gates. [Figure 02] 
Figure 2. Curtilage organization layout, extending parallel to the contour lines.

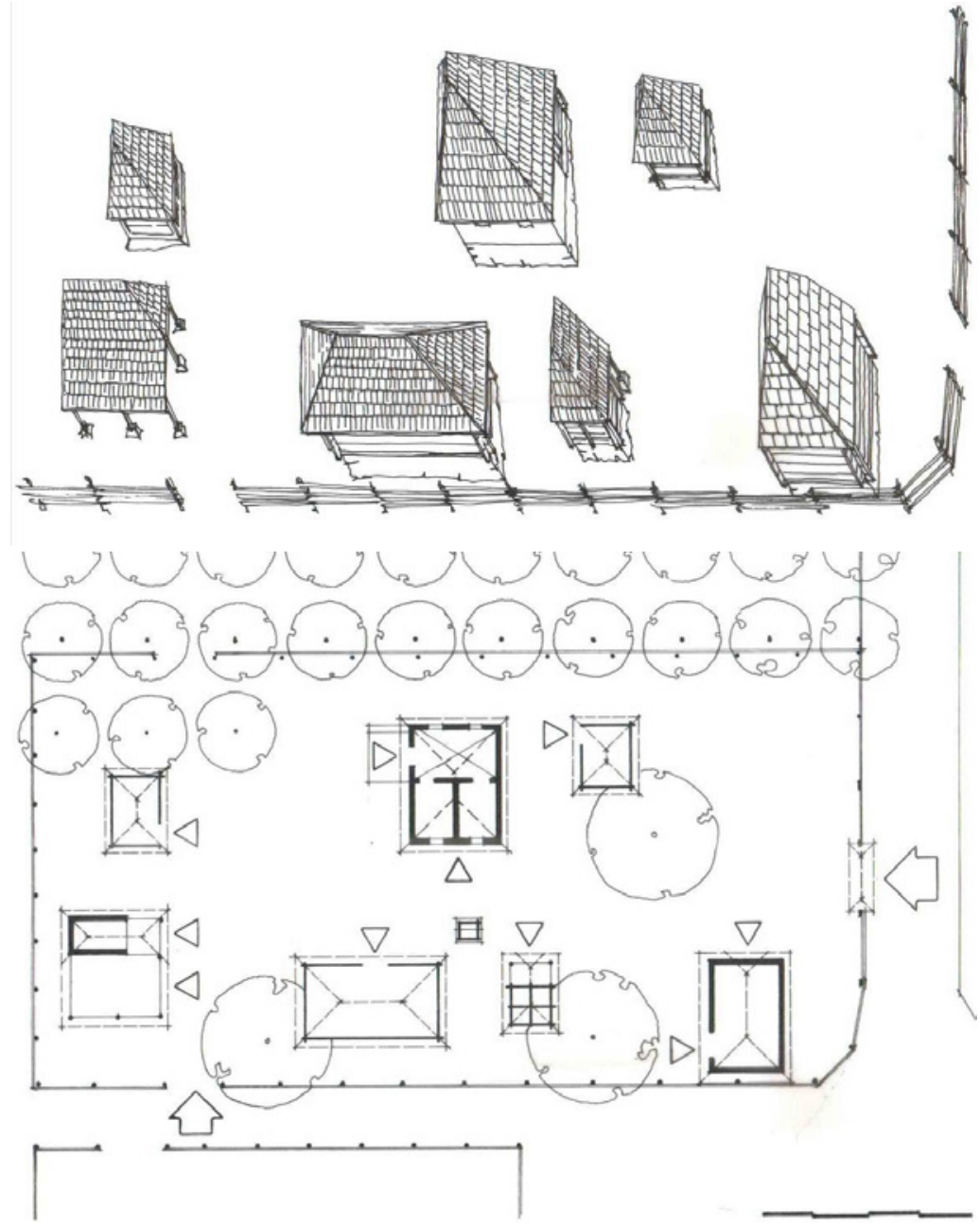

Source: Work of author

House according to the organization, consists of three parts. It contains a "house" and two rooms. The house is built on a basement made of dressed stone bonded with limestone mortar, with a room in it, with the entrance door on the front side and with one window at the middle of each of the lateral sides; the floor is made of rammed earth or of fired bricks laid on their wide side, while the post which supports the beam is rested on the foundation footing made of hewn stone. The walls of the building are constructed as post-and-pan structure, with an infill of adobe covered with mortar on both sides. The double windows consist of two parts, and the doors are divided in panels. The flooring in the rooms is wooden. The ceiling is made of reed covered with limestone mortar. The roof is hipped, covered with regularly laid stone slabs. [Figure 03] 
Figure 3. Adobe house on the basement, covered with stone slabs, village of Godečevo

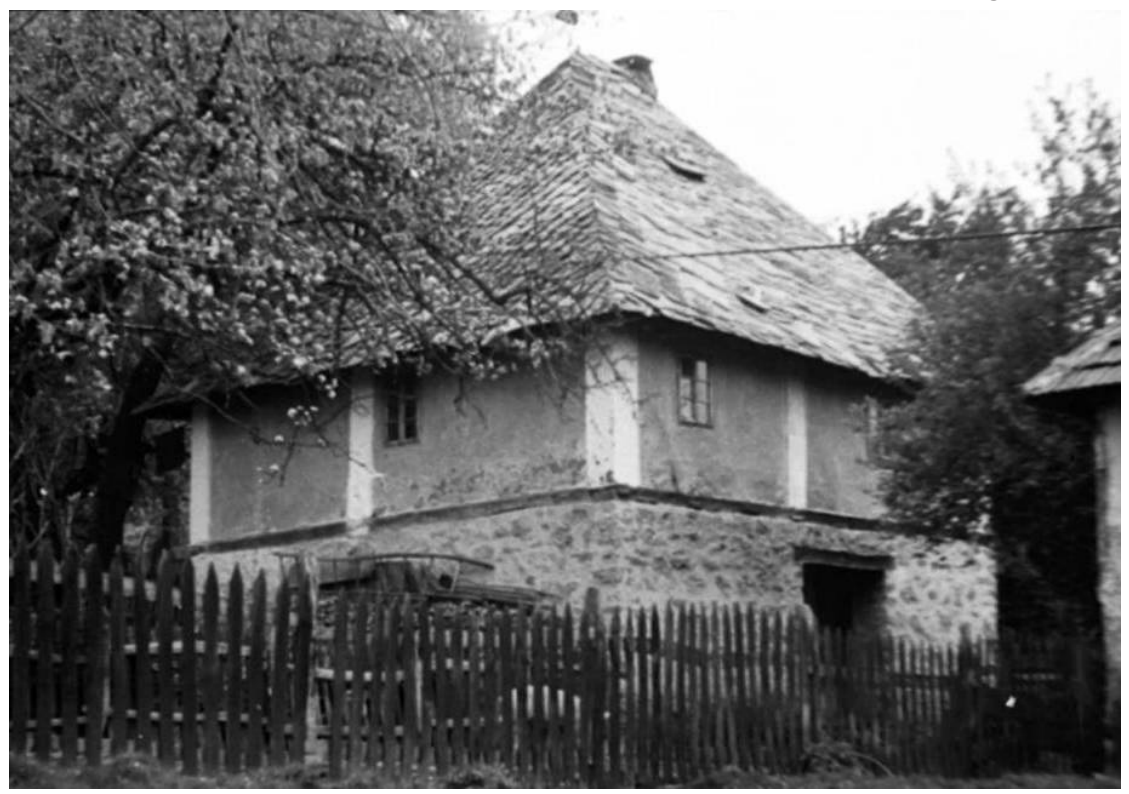

Source: Work of author

Magaza is represented by two types of structures: with or without a basement.

The first example is the building made on the hewn stone foundations, of approximately square layout, with the walls of hewn planks joined at the corners by double notched joints. One of the building sides, owing to its length, includes a post in its middle, over which the wall consisting of wooden planks connected by tenon-and-mortise joint is made. The roof is hipped, and the cover is made of stone slabs. [Figure 04]

The second example has the main structure with a cellar whose wall is made of the hewn stone bonded with limestone mortar. The floor of the cellar is made of rammed earth, and the door has two wings. The walls of the building are made of a wooden frame with a horizontal bracing frame. The walls are infilled with hewn planks connected to the columns by mortise and tenon joints. The door has one wing, and it is positioned on the middle of the facade. The roof is hipped and the roof cover is made of irregularly laid stone slabs. One of the eaves is longer than the others, so as to provide cover for the shelf with the ,vrškara“" type beehives. [Figure 05] 
Figure 4. Magaza, village of Godečevo.

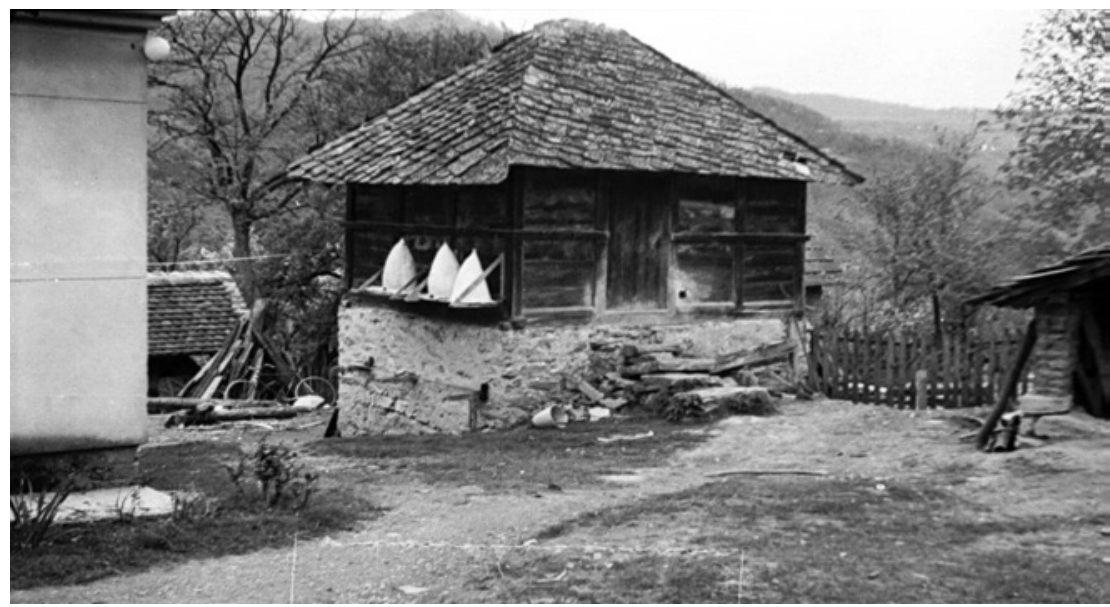

Source: Work of author

Figure 5. Magaza, village of Godečevo

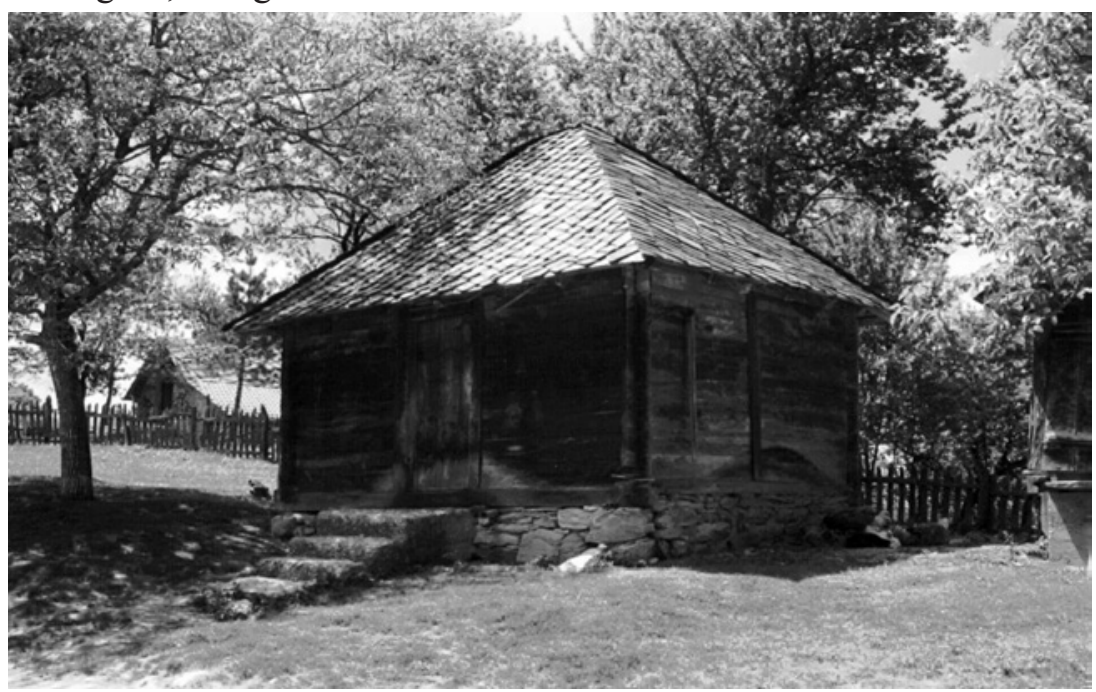

Source: Work of author

Kačara is a building used to store casks and kegs with brandy, and it is made entirely of timber, on the strip foundations made of hewn stone bonded by limestone mortar. The walls of the building are made of timber, connected at the corners by double notched joints. At the middle of the span, there is a wooden post with a mortise which connects two sides of the structure with hewn planks into one facade plane. The doors have two wings and a wooden lock, and they are located on the middle of the longer façade. The roof is hipped, covered by regularly laid stone slabs. [Figure 06] 
Figure 6. Kačara, selo Godečevo

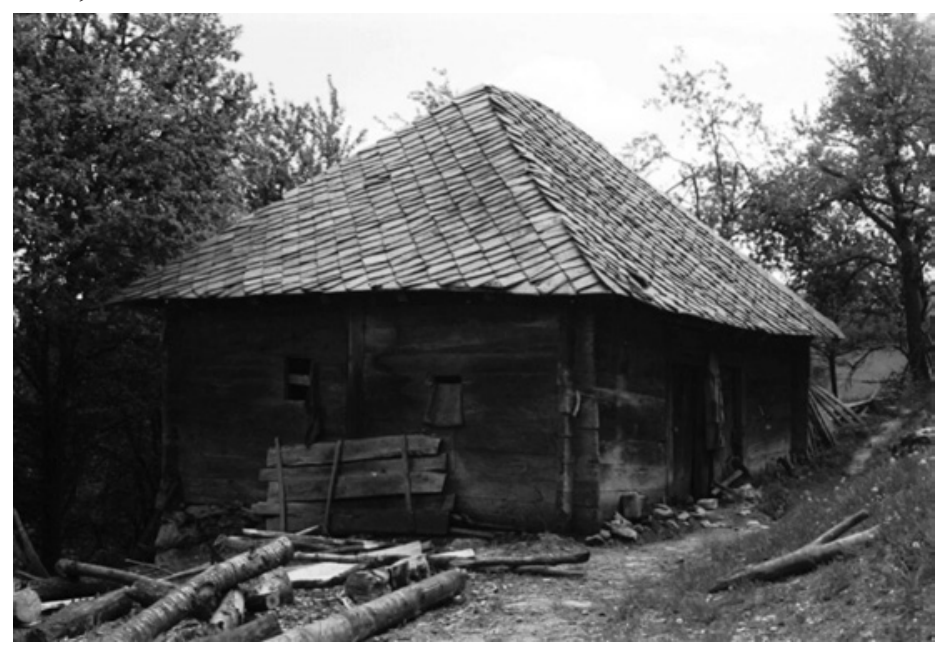

Source: Work of author

Vajat - there are two types of vajati in curtilages.

Type one is made in a frame, filled with vertical ,ک̌ašovac“ elements - wooden strips. It is supported on the strips foundations of hewn stone bonded by limestone mortar. The roof is hipped, covered by irregularly laid stone slabs. [Figure 07]

Type two is made of a frame, filled by two kinds of infill: the bottom part is made of hewn horizontal boards, and the upper part (up to the top plate) is filled in by wooden strips. Vajat is supported by stone footings. The roof is hipped, covered by shingles. [Figure 08]

Figure 7. Vajat with a frame and infill "na šašovce" (wooden strips)

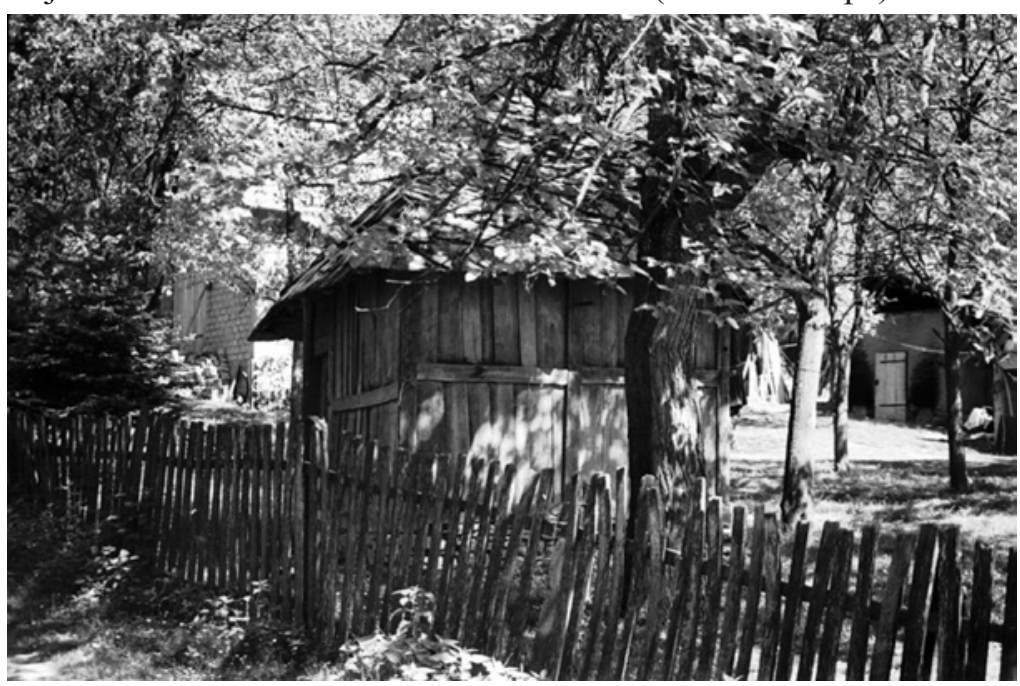

Source: Work of author 
Figure 8. Vajat with a frame and ("na unizu") tenon and mortise joints and wooden stips infill ("na šašovce")

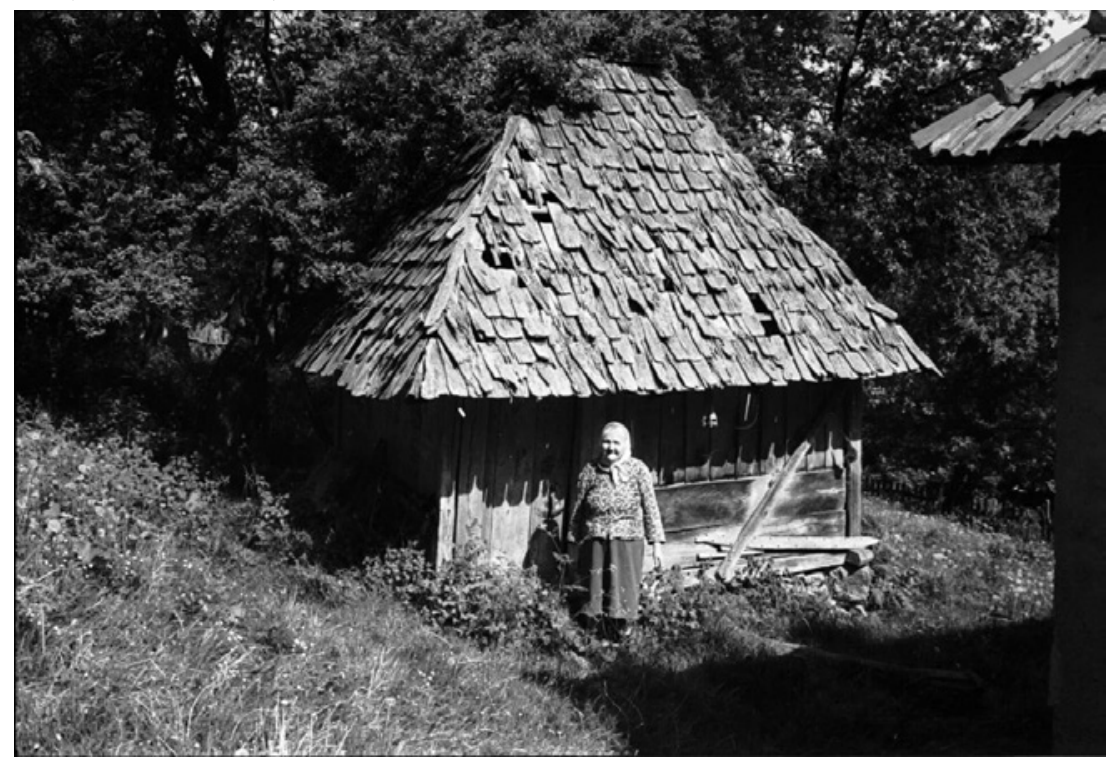

Source: Work of author

Maize granary consists of two horizontal planks, connected with four pairs of posts. It is supported by three hewn stone foundation footings. The roof is covered by shingles. [Figure 09]

Figure 9. Granary with three groups of single posts in Godečevo

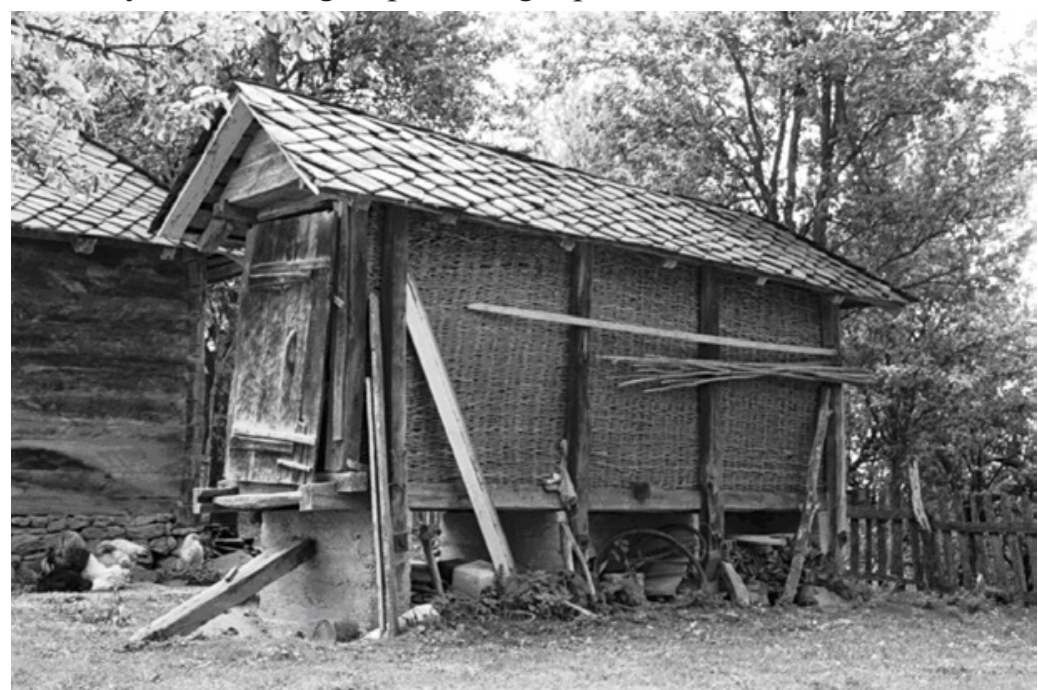

Source: Work of author 
Granary has four compartments and wide eaves, it is built on four foundation footings at the corners of the building, with a three-plane roof, and a cover of stone slabs. [Figure 10]

Figure 10. Granary covered by stone slabs from Godečevo

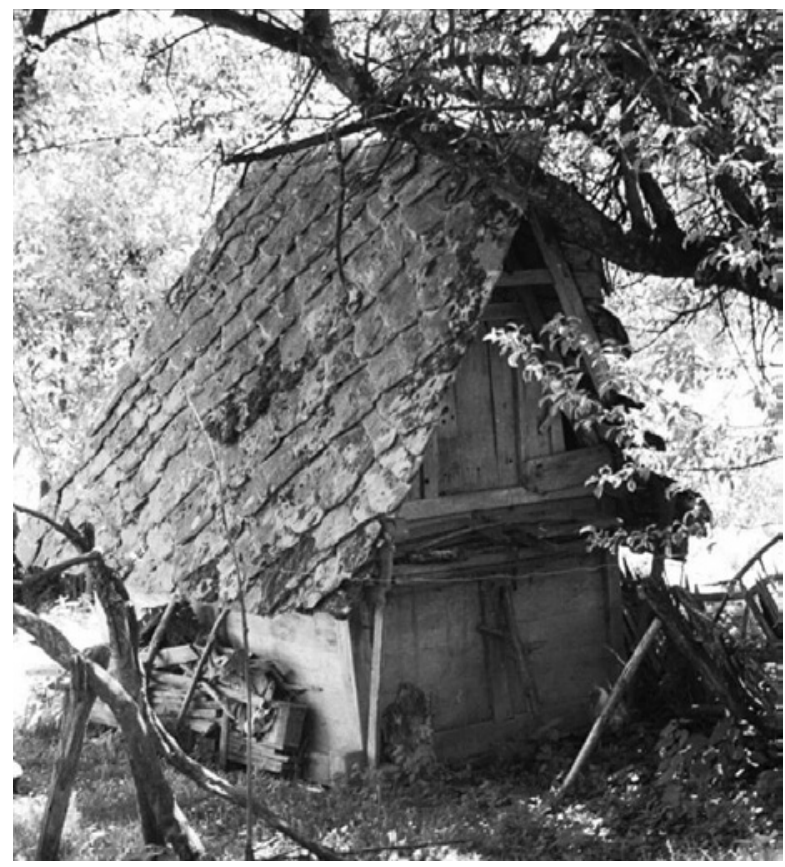

Source: Work of author

Bread oven is made of massive timber on a skeleton, on a plinth of hewn stone. The three-plane roof is covered by stone slabs. [Figure 11]

Figure 11. Bread oven from Jaklje

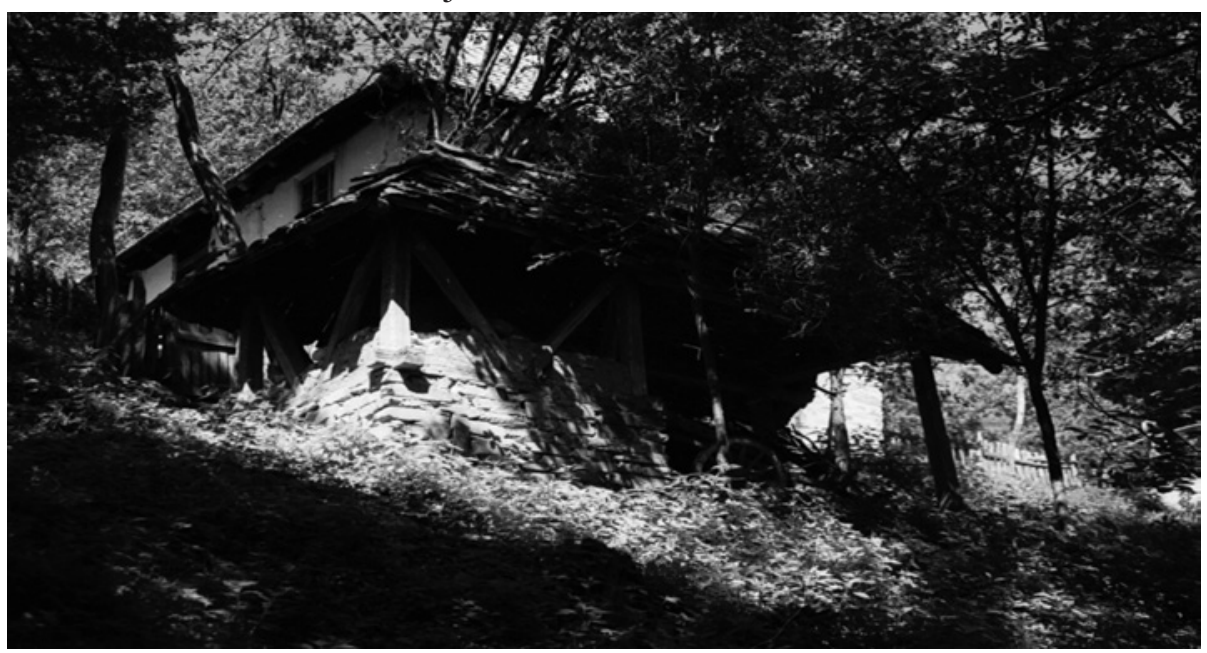

Source: Work of author

EP 2017 (64) 1 (239-257) 
Drying shed for plum is made of a masonry skeleton on the foundations of hewn stone in lime mortar. The three-plane roof is covered by stone slabs. [Figure 12]

Figure 12. Drying shed for plum from Godečevo

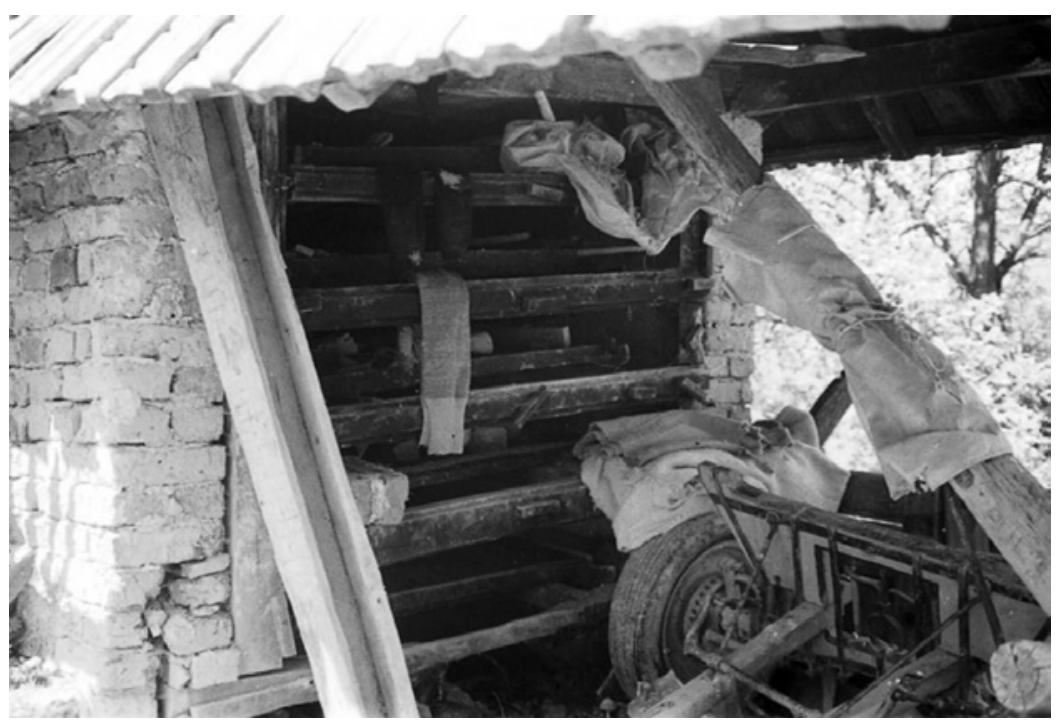

Source: Work of author

Figure 13. Wattle fence from Godečevo

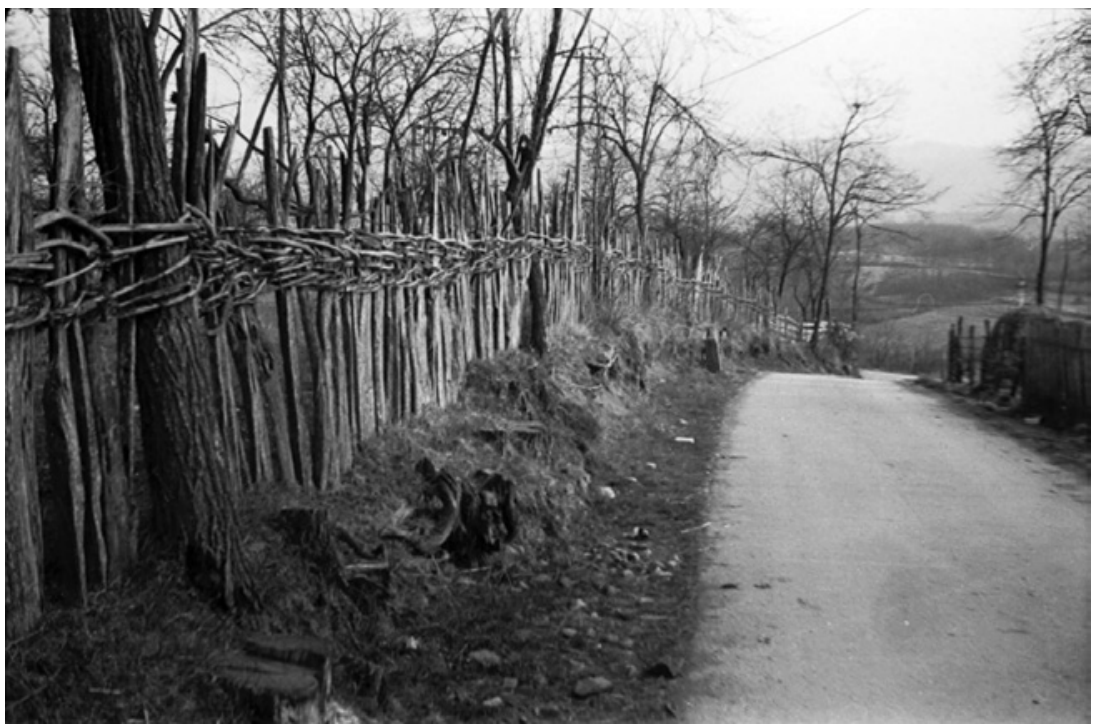

Source: Work of author

Curtilage fence is made of wattle, the gate has no roof. 


\section{Representative village curtilage of Valjevo Podgorina}

The curtilage consists of: house, guest house, two vajat outbuildings, magaza, kačara, granary, maize granary and stable. [Figure 14]

House presents two stages in development of housing buildings during $19^{\text {th }}$ and first half of $20^{\text {th }}$ century in this part of Serbia. The first example (half of $19^{\text {th }}$ century) is a two-room house on a high pedestal, which apart from presenting the level of housing, meets all the conditions so as to represent a guest house as well. The second example is the house dating back to the end of $19^{\text {th }}$ century, known as „Bogatinka“.

Example 1 presents the house (half of $19^{\text {th }}$ century) which consists of the high pedestal (made of hewn stone bonded by limestone mortar) which contains a cellar, while the main body of the building consists of two rooms and a porch (made in post-and-pan system, with an adobe infill). The wall is covered with mortar and painted on both sides. The floor in the rooms is made of floorboards and the ceiling of wooden strips (,šašovci“). The porch fence is made of wooden strips. The roof is hipped, and the roof cover is S-tile. [Figure 15]

Example 2 presents the house named „Bogatinka. The house consists of three rooms: a "house" and two rooms. The foundation is made of hewn stone, the wall is made of fired bricks bonded by limestone mortar, and it is plastered and painted. In the rooms, the floor is made of floorboards, and in the "house" it is made of the bricks laid on their wide side. The ceiling is made of mortar on the reed. The roof is hipped, and the cover is single laid crown tile. [Figure 16]

Figure 14. Curtilage of Valjevo Podgorina villages.

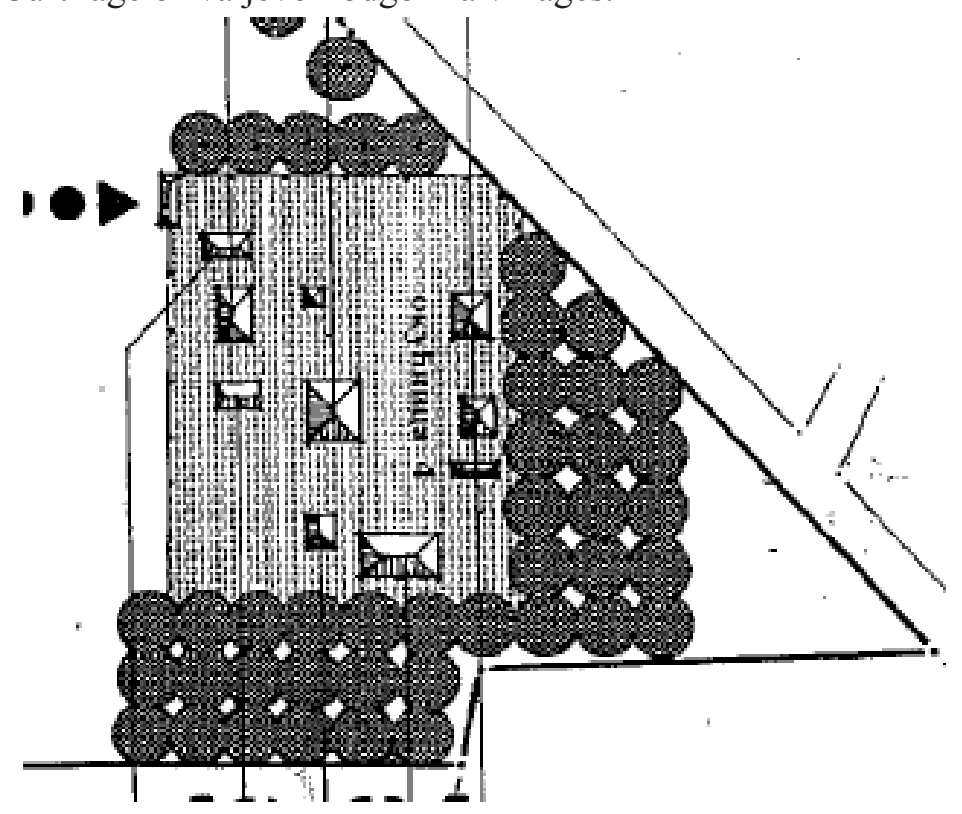

Source: Work of author

EP 2017 (64) 1 (239-257) 
Figure 15. The Velimir Urošević's house, village of Virovci, (around 1850)
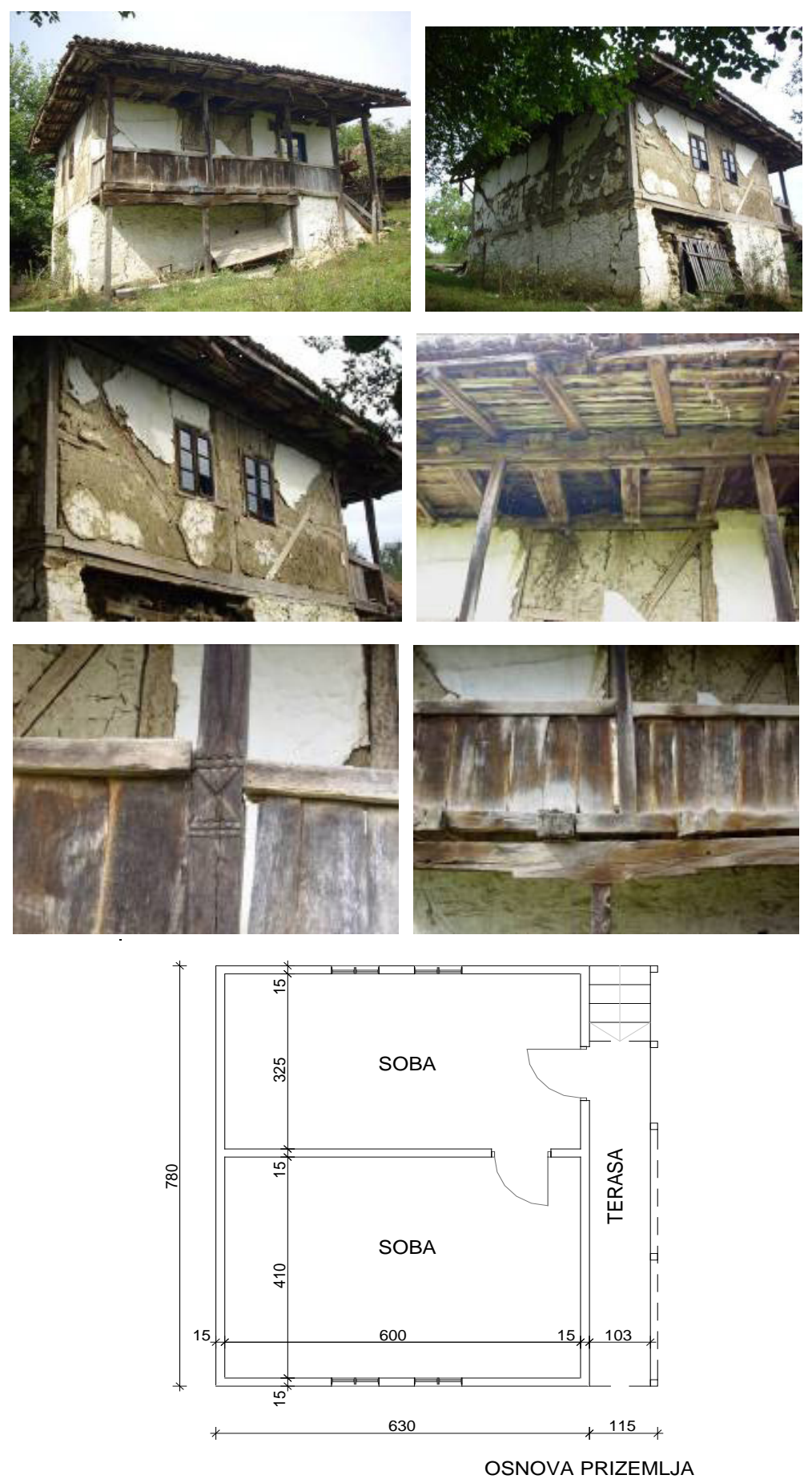

Source: Work of author 
Figure 16. The Stevanović's house, village of Bogatić, (around 1880)
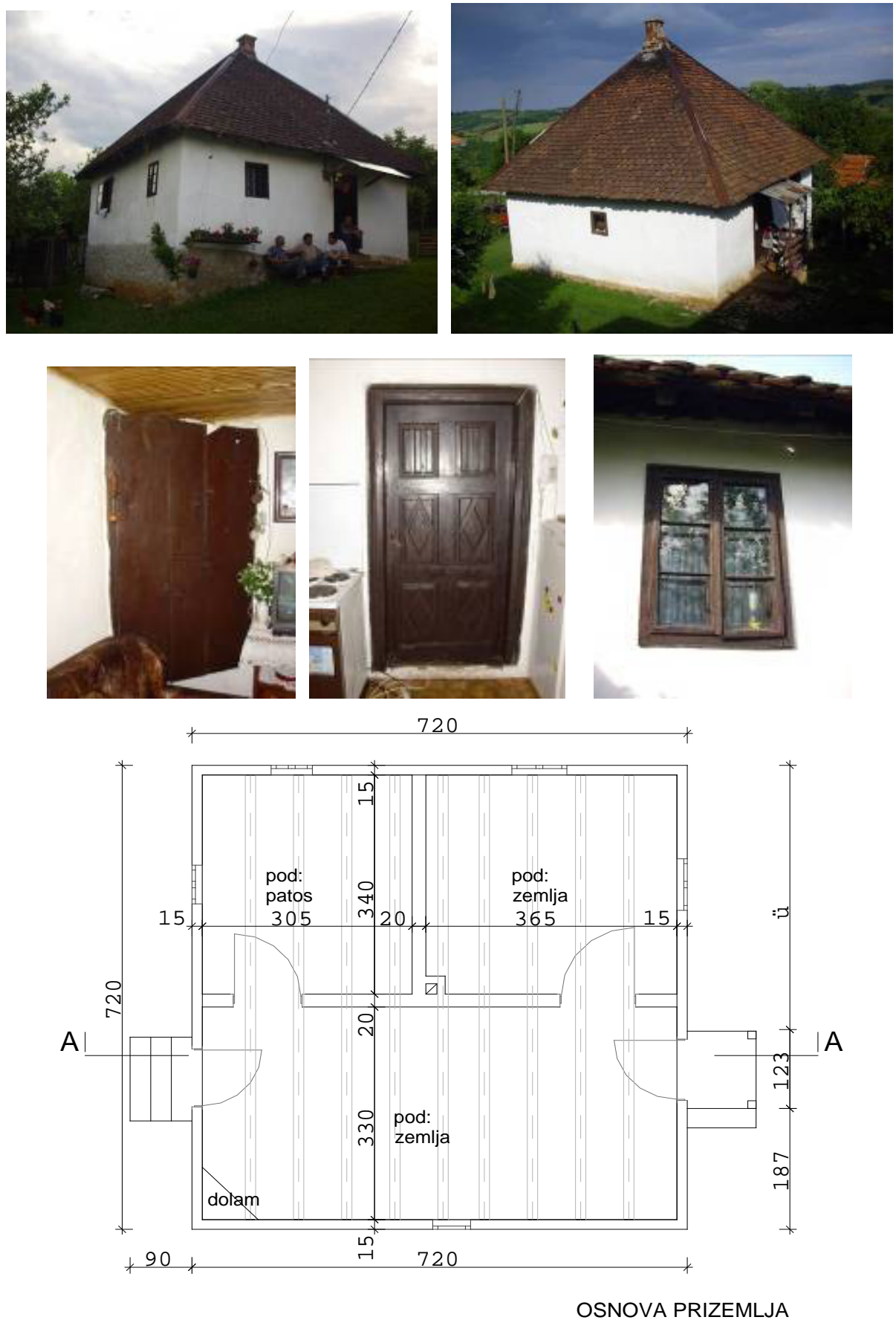

Source: Work of author 
Magaza is presented by two types: magaza with a porch and without it.

Example 1 consists of one room, on the foundations on hewn stone in a skeleton made of massive timber and with the infill of hewn boards. The roof is hipped, covered by crown tile. [Figure 17]

Example 2 of the building consists of two rooms: closed room and the porch. The main building is made of wooden frame and filled in by horizontally laid hewn boards. The porch fence has a wooden beam on its top, and the parapet is made of vertical wooden strips. The roof is hipped, covered by crown tile [Figure 18]

Figure 17. Magaza, village of Brajkovići.

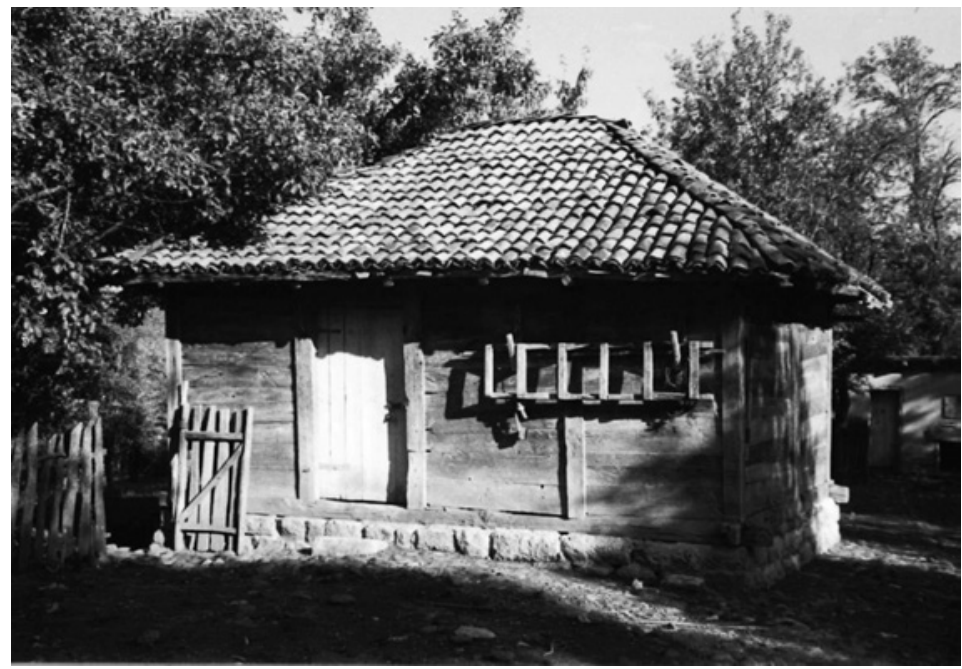

Source: Work of author

Figure 18. Magaza with a porch, village of Mionica.

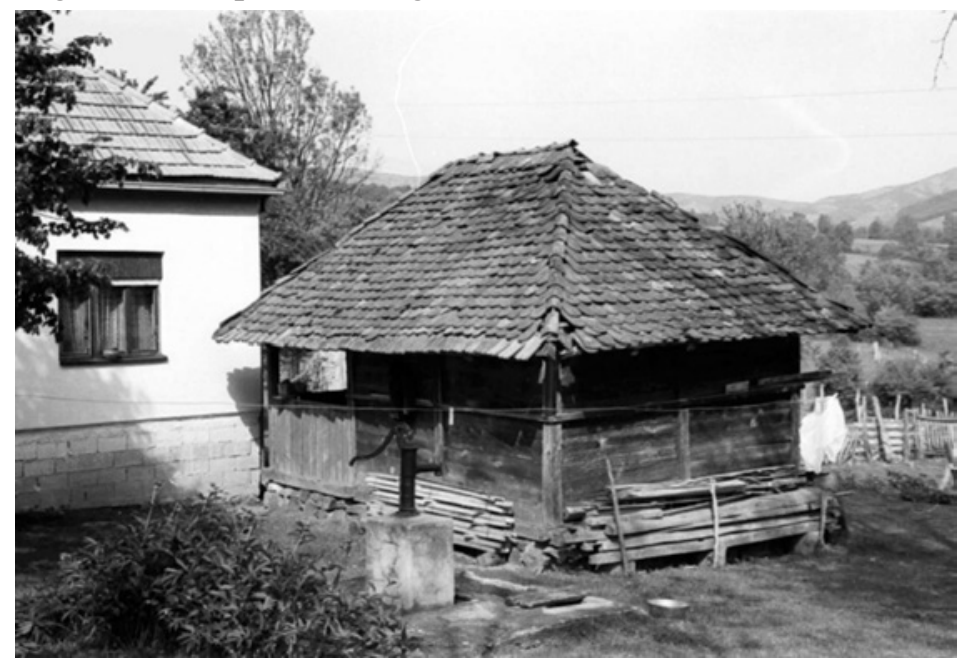

Source: Work of author 
Kačara is a single room structure built on a sloped terrain. It contains a basement, cask shed at the ground level, and a storage room in the attic. The basement is built of hewn stone bonded by limestone mortar, and the main body of the building is a skeleton with an infill of wooden planks, while the roof has three planes, with a crown tile cover. [Figure 19]

Figure 19. Kačara, village of Brajkovići.

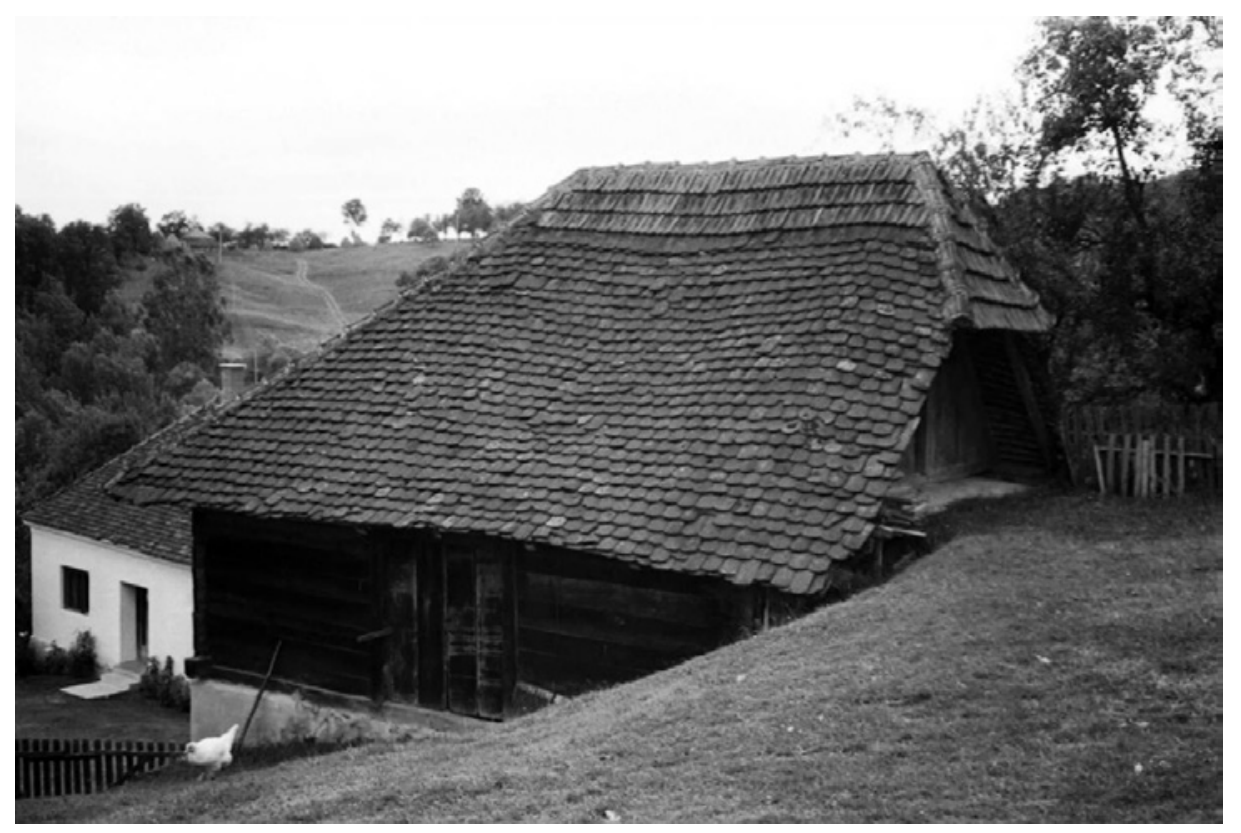

Source: Work of author

Vajat is presented by two types: vajat with the building body made of wooden planks joined with double notched joints, and vajat with the skeleton frame with an infill of wooden planks joined by tenon-and-mortise joint.

Example 1 is set on the strip foundations made of hewn stone. A bottom beam is laid along the bottom, and above it are the rows of wooden planks connected at the corners by double notched joints, the final row being the top plate. The roof is hipped, and the cover is crown tile. [Figure 20]

Example 2 is a structure made in a skeleton made of massive timber with a wooden plank infill. The roof is hipped, and the cover is S tile. [Figure 21]

Granary has four compartments for grain, with a three-plane roof covered with crown tile. [Figure 22]

Maize granary consists of a building body, supported on three supports made of masonry pieces, made of massive timber with vertical posts and braces. The infill is wattle, with a three-plane roof covered with crown tile. 
Ox Cart shed is made in a massive timber frame, supported by foundation footings of hewn stones, with a gable roof covered with crown tile.

The fence of the curtilage is made of wattle, the gate has a gable roof, covered with crown tile.

Figure 20. Vajat made wooden planks joined with double notch joint

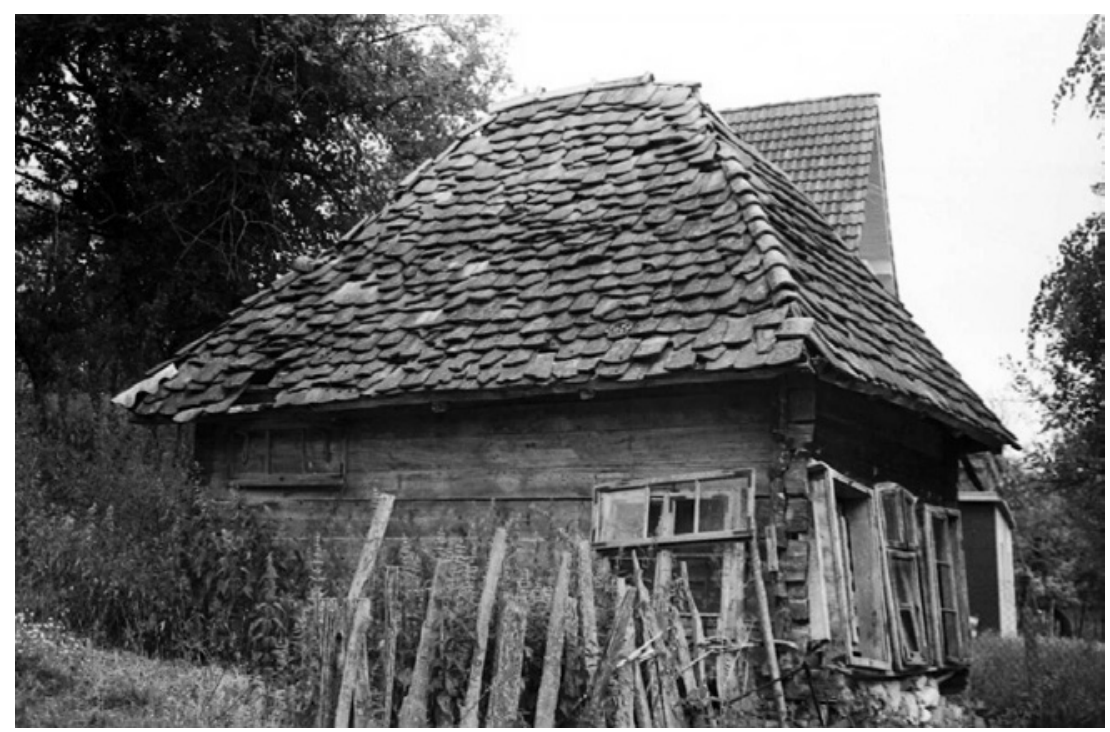

Source: Work of author

Figure 21. Vajat made wooden planks joined with tenon-and-mortise joint.

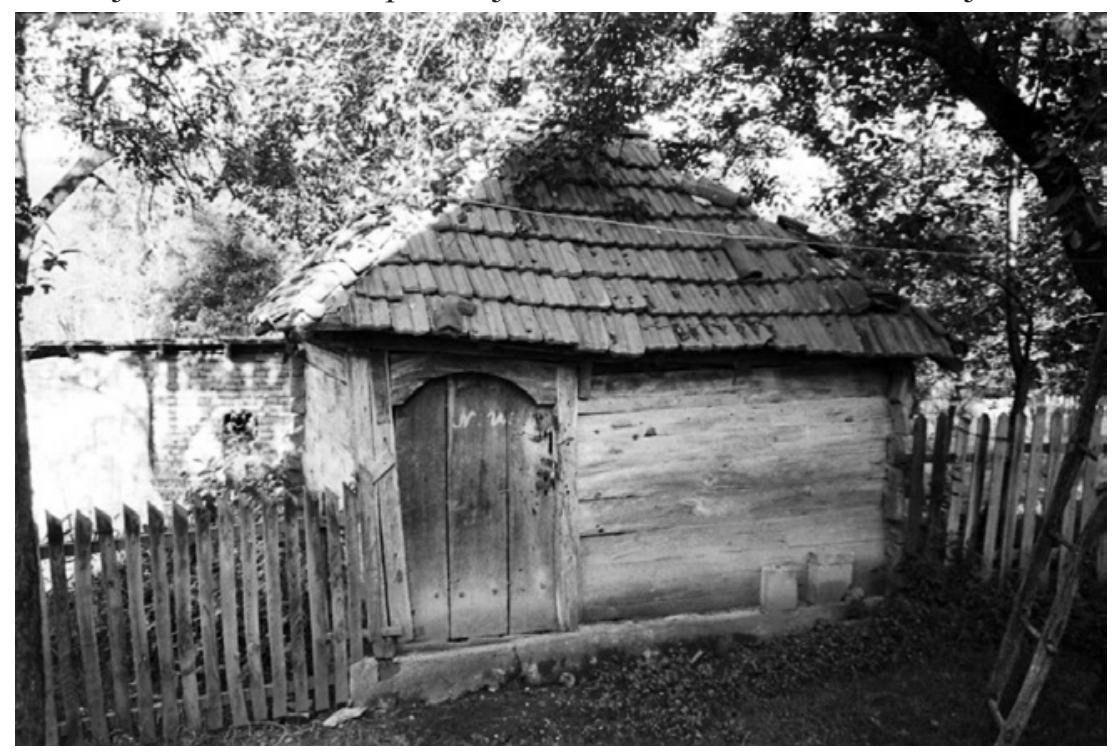

Source: Work of author 
Figure 22. Granary with a wide front eave from the village of Godečevo (roof cover replaced)

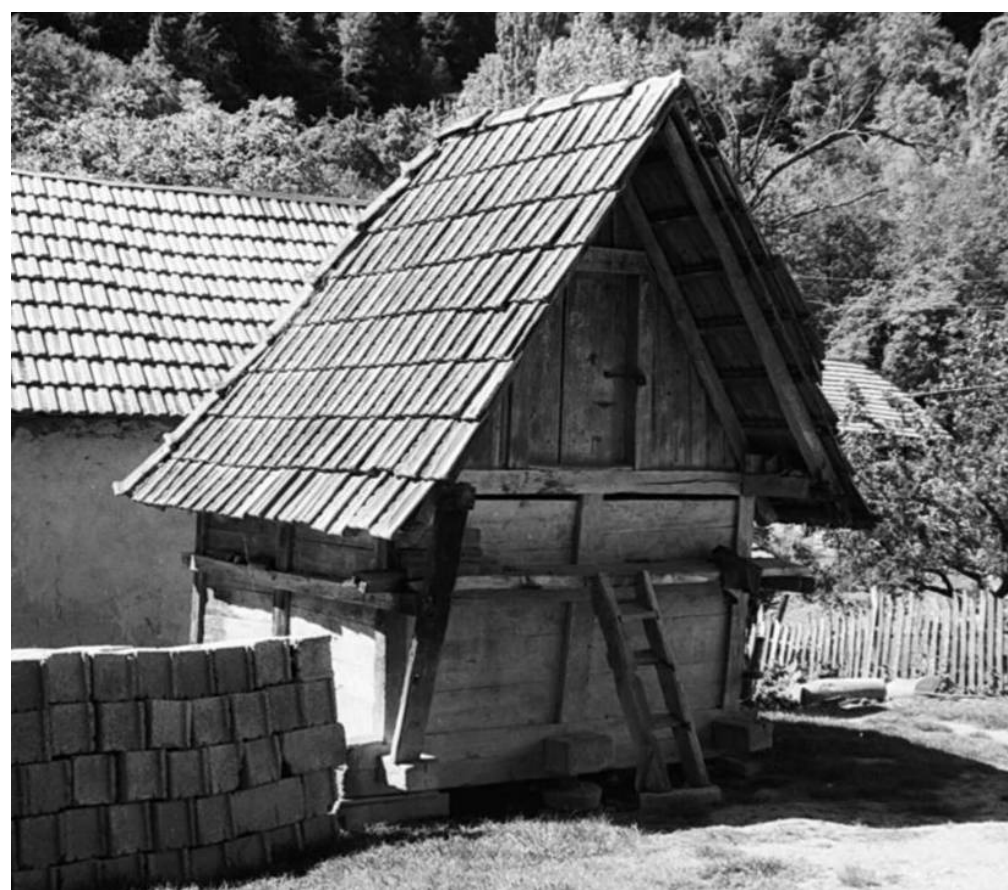

Source: Work of author

\section{Conclusion}

The Museum of vernacular architecture of western Serbia preserves and presents the representative and characteristic specimens of traditional architecture made during $19^{\text {th }}$ and the first half of $20^{\text {th }}$ century. The goal of the museum is to preserve the original samples of architecture which feature the elements of form, workmanship, traces of tools and traces of utilization of structures, etc. The museum consists of four characteristic curtilages and four characteristic entities. In this paper two curtilages representing the area of the middle course of the Drina and Kolubara rivers are analyzed. Each of the curtilages consists of a house, magaza, kačara, vajat, maize granary, granary, and fence. The buildings represent characteristic ways of organization of structures or of the structural design of certain details or of entire buildings. Since the buildings of national architecture vanish on a daily basis, it is necessary to urgently undertake all necessary activities to preserve them, by organizing the Museum.

\section{References}

1. Aličić, A. (1985): Turski katastarski popisi nekih područja zapadne Srbije 15 i 16.v, Čačak.

2. Deroko, A. (1964): Folklorna arhitektura u Jugoslaviji, Beograd. 
3. Deroko, A. (1968): Narodno neimarstvo 1 i 2, Beograd,;

4. Etnografski muzej (2009): Sve, sve, ali zanat (katalog izložbe), Beograd.

5. Kadić, M. (1967): Starinska seoska kuća u Bosni i Hercegovini, Sarajevo.

6. Kanic,F. (1985): Srbija - zemlja i stanovništvo, Beograd.

7. Karanović, M. (1927): O tipovima kuća u Bosni, Glasnik zemljskog muzeja BiH, Sarajevo, no. 39, pp. 207-217.

8. Kojić, B. (1941): Arhitektura srpskog sela - Šumadija i Pomoravlje, Beograd.

9. Kojić, B. (1949): Stara gradska i seoska arhitektura u Srbiji, Beograd.

10. Kreševljaković, H. (1957): Hanovi i karavansaraji u Bosni i Hercegovini, Naučno društvo NR BiH, Sarajevo.

11. Krstanović, B. (2000): Dinarska dvodelna kuća u oblasti istočne Srbije - prilog za tipologiju narodnog graditeljstva Srbije, Glasnik Etnografskog instituta SANU, no. 49, pp. 207-216;

12. Krunić, J. (1983): Dinarska dvodelna kuća - njen značaj i razvoj, Užički zbornik no. 12, p. 354;

13. Kuzović, D. (1996): Folkarchitecture in Kosjerić, International conference "Architecture and urbanism at the turn of the III millenium", Faculty of Architecture University of Belgrade, Belgrade, Yugoslavia, Vol. 1, pp. 589-595.

14. Kuzović, D. (1996/1997): Narodno graditeljstvo na prostoru opštine Kosjerić, Užički zbornik, no. 25/26, pp. 365-380, Narodni muzej Užice.

15. Kuzović, D. (2012): “Constructive solutions of cabins on southern slopes of Povlen mountain”, International conference „Science and higher education in function of sustainable development - SED 2012“, Užice.

16. Kuzović, D. (2012): „Ambari na južnim padinama planine Povlen“, u: Glasnik Istorijskog arhiva u Valjevu, Valjevo, no. 46,: pp.108-117, ISSN 0350-9143, UDK 725.36 .

17. Kuzović, D. (2012): „Konstruktivna rešenja korpusa ruralnih objekata na južnim padinama planine Povlen“, u: Glasnik Etnografskog muzeja u Beogradu, Beograd, vol. 76: pp. 193-213.

18. Kuzović, D. (2013): „Koševi za kukuruz na južnim padinama planine Povlen“, u: Glasnik Istorijskog arhiva u Valjevu, Valjevo, br. 47,: str.83-99.

19. Kuzović, D. (2013): „Magaze i kačare na prostoru južnih padina planine Povlen“, u: Glasnik Etnografskog muzeja u Beogradu, Beograd, vol. 77: pp. 121-149.

20. Kuzović, D. (2013): „Prihodi od kulturne baštine“, u: Glasnik Društva konzervatora Srbije, Beograd, no. 37, pp. 43-46.

21. Kuzović, D. (2013): „Seoska kuća na južnim padinama planine Povlen“, vol. 2, no. 143, Zbornik Matice srpske za društvene nauke, Novi Sad.

22. Kuzović, D. (2014): "Konstruisanje arhitektonskog prostora u tradicionalnoj i savremenoj kulturi na Balkanu - Mikroklimat i prostor" (koautor), Tradicionalna 
estetska kultura 9: Prostor, Centar za naučnoistraživački rad SANU i Univerziteta u Nišu, Niš.

23. Kuzović, D. (2014): „Karakteristične etape razvoja seoske okućnice u selima na južnim padinama planine Povlen“, u: Izgradnja, vol. 68, No. 11-12, pp. 495-500.

24. Kuzović, D. (2015): „Arhitektonsko nasleđe i tržište“, u: Kultura Polisa, Institut za evropske studije, Beograd, vol. 26: pp. 119-129, ISSN 1820-4589.

25. Kuzović, D. (2015): „Prihod od arhitektonske baštine - osnove, karakteristike, potencijali“،, , u: Kultura, Zavod za proučavanje kulturnog razvitka Srbije, Beograd, no. 146, pp. 238-249.

26. Kuzović, D., Krsmanović, Ž. (2013): „Arhitektura seoske kuće u Valjevskoj Kolubari i Podgorini“" u: Glasnik Etnografskog muzeja u Beogradu, Beograd, vol. 77, pp. 85-121.

27. Kuzović, D., Stojnić, N. (2013): “Estetika alata osaćanskih neimara”, Tradicionalna estetska kultura 8: Alat, Centar za naučnoistraživački rad SANU i Univerziteta u Nišu, Niš.

28. Kuzović, D., Stojnić, N. (2015): „Arhitektura vodenica potočara u centralnom delu Zapadne Srbije i Istone Bosne“", u: Zbornik Matice srpske za društvene nauke, no. 150, pp. 773-801.

29. Kuzović, D., Stojnić, N. (2015): „Letnji stanovi stočara na planini Povlen“, Zbornik Matice srpske za društvene nauke, No. 150, pp. 129-156.

30. Obradović, S. (1858): Opisanije okruga užičkog, Beograd.

31. Pavlović, Lj. (1925): Užička Crna Gora, Beograd,

32. Pavlović, Lj. (1930): Sokolska nahija, Beograd.

33. Pantelić, D. (1936): Vojno-geografski opisi Srbije pred Kočinu krajinu od 1783. i 1784. god, Beograd.

34. Pešić, B. (1988): Tradicionalna seoska kuća opštine Raška, Glasnik DKS 12, p. $112-$ 113.

35. Pešić, B. (1991): O proporcijama dinarske kuće, Glasnik DKS 15, p. 109-112.

36. Soldo, Š. (1932): Tipovi kuća i zgrada u pređašnjoj Bosni i Hercegovini, Beograd.

37. Findrik, R. (1995): Narodno neimarstvo, Sirogojno.

38. Findrik, R. (1998): Dinarska brvnara, Sirogojno.

39. Findrik, R. (1999): Vajati, znamenja mladosti, Sirogojno.

40.Cvijić, J. (1931): Balkansko poluostrvo, Beograd. 
ECONOMICS OF

AGRICULTURE

\section{CONTENT}

1. Željko Anđelković, Aleksandra Dragin, Sanja Božić, Kristina Košić

EMOTIONAL EXHAUSTION AND JOB SATISFACTION OF TOUR GUIDES IN RURAL AREAS . . . . . . . . . . . . . . 11

2. Sanja Đukić, Danica Glavaš-Trbić, Nikola Banjac

MANAGEMENT PROBLEMS OF RURAL DEVELOPMENT IN FRUŠKA GORA . . . . . . . . . . . . . . . . . . . . 27

3. Ivana Ilić, Bojan Krstić, Sonja Jovanović

ENVIRONMENTAL PERFORMANCES OF AGRICULTURE IN THE EUROPEAN UNION COUNTRIES . . . . . . . . . . . . . 41

4. Nataša Kljajić, Jonel Subić, Zorica Sredojević

PROFITABILITY OF RASPBERRY PRODUCTION

ON HOLDINGS IN THE TERRITORY OF ARILJE. . . . . . . . . . . 57

5. Aleksandar Maksimović, Zoran Grgić, Ferhat Ćejvanović

MULTI-ATTRIBUTE ANALYSIS OF ORCHARD ACCORDING

TO THE INTEGRATED PRODUCTION CONCEPT . . . . . . . . . . 69

6. Ozrislava Milinković, Branislav Jakić, Slobodan Vuksanović,

Dragana Macura, Milica Šelmić

MULTI- CRITERIA DECISION BASED APPROACH

TO SELECTING THE TYPE OF INDUSTRIAL HALLS

USED IN FOOD INDUSTRY $\ldots \ldots \ldots \ldots$. . . . . . . . . . 81

7. Gordana Nikić, Ljubiša Stamatović, Azra Sućeska

EMOTIONAL COMPETENCIES AND PERSONALITY

TRAITS OF MANAGERS IN MODERN AGROBUSINESS. . . . . . . .97

8. Vladimir Obradović, Nemanja Karapavlović

FINANCIAL REPORTING OF COMPREHENSIVE INCOME

IN THE FOOD AND BEVERAGE SECTOR

IN THE REPUBLIC OF SERBIA . . . . . . . . . . . . . . 113 
9. Aleksandar Ostojić, Nebojša Savić, Željko Vaško

CONSUMER ATTITUDES

ON BUYING FISH IN BANJA LUKA . . . . . . . . . . . . . . . 129

10. Radivoj Prodanović, Boris Kuzman, David Jovović, Lazar Ozegović

MARKET AND TRADE OF ORGANIC FRUITS IN SERBIA $\ldots . . .141$

11. Predrag Vukadinović, Aleksandar Damnjanović, Ljiljana Dimitrijević

ANALYSIS OF THE SALES AND INCOMES BETWEEN

DIFFERENT CATEGORIES OF AGRICULTURAL PRODUCTS . . . 157

12. Jugoslav Aničić, Svetlana Vukotić, Goran Maksimović

THE POSSIBILITIES AND LIMITATIONS

OF ENTREPRENEURSHIP DEVELOPMENT

IN AGRICULTURE IN SERBIA . . . . . . . . . . . . . . 171

13. Željko Bjelajac, Marijana Dukić - Mijatović, Joko Dragojlović

FOOD SAFETY AS ONE OF THE MAIN SAFETY $P$

REOCCUPATIONS OF A MODERN MAN . . . . . . . . . . . . . 191

14. Milan Bradić, Ljiljana Kosar, Lukrecija Djeri, Svetlana Vukosav, Vuk Garača

ECO-LABELLING OF ACCOMMODATION FACILITIES

AND ITS PERCEPTION BY RURAL TOURISTS:

CASE STUDY OF VOJVODINA . . . . . . . . . . . . . . 205

15. Vaso Jegdić, Iva Škrbić, Srđan Milošević

MODELS OF ENTREPRENURSHIP DEVELOPMENT

IN RURAL TOURISM DESTINATIONS IN VOJVODINA . . . . . . . 221

16. Duško Kuzović

MUSEUM OF VERNACULAR ARCHITECTURE OF WESTERN SERBIA

- Representative curtilages of the area surrounding middle

course of the river Drina and Podgorina . . . . . . . . . . . 239

17. Branko Mihailović, Zoran Simonović, Nikola Ćurčić

AGRICULTURAL RESOURCES AND DEVELOPMENT

PRIORITIES OF THE MUNICIPALITY OF STARA PAZOVA. . . . . 259

18. Radmilo Nikolić, Aleksandra Fedajev, Vidoje Stefanović, Silvana Ilić

THE AGRICULTURE SECTOR IN WESTERN BALKANS

- SOME CHARACTERISTICS OF DEVELOPMENT. . . . . . . . . . 275

19. Vladimir Njegomir, Rajko Tepavac, Nenad Ivanišević

ALTERNATIVE SOURCES OF FINANCING

ENTREPRENEURIAL UNDERTAKINGS IN AGRICULTURE . . . 295

Economics of Agriculture, Year 64, No. 1 (1-404) 2017, Belgrade 
20. Daniela Nuševa, Kristina Mijić, Dejan Jakšić

THE PERFORMANCES OF COFFEE PROCESSORS

AND COFFEE MARKET IN THE REPUBLIC OF SERBIA . . . . . . 307

21. Svetlana Roljević Nikolić, Predrag Vuković, Biljana Grujić

MEASURES TO SUPPORT THE DEVELOPMENT OF ORGANIC

FARMING IN THE EU AND SERBIA . . . . . . . . . . . . 323

22. ŽeljkoVojinović, Vera Zelenović, DragoCvijanović

PROGRAM OF STATE SUPPORT

TO AGRICULTURAL CREDITING. . . . . . . . . . . . . . . . 339

23. Nikola Vuksanović, Dragan Tešanović, Bojana Kalenjuk,

Milijanko Portić, Marija Knežević

SOCIO-DEMOGRAPHIC CHARACTERISTICS

AS DETERMINANTS OF DIFFERENCES

IN PERCEPTION OF LOCAL GASTRONOMY . . . . . . . . . . . . 359 